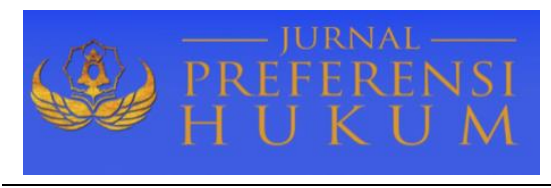

Jurnal Preferensi Hukum | ISSN: XXXX | E-ISSN: XXXX

Vol. 1, No. 2 - September 2020, Hal. 121-127| Available Online at https://www.ejournal.warmadewa.ac.id/index.php/juprehum

DOI: http://doi.org/10.22225/jph.v1i2.2407.121-127

\title{
PERLINDUNGAN HUKUM TERHADAP PEKERJA YANG BEKERJA MELEBIHI WAKTU KERJA (STUDI PADA PERUSAHAAN UD. INDRA JAYA SEAFOOD SUPPLIER)
}

\author{
Ayu Adi Ulansari \\ Fakultas Hukum Universitas Warmadewa, Denpasar-Bali, Indonesia
}

\begin{abstract}
Abstrak
Pekerjaan yang dikerjakan di luar jam kerja merupakan suatu hal yang di luar kewajiban para pekerja. Penelitian ini bertujuan untuk menganalisis implementasi perlindungan hukum terhadap pekerja yang bekerja diluar waktu kerja pada perusahaan UD. Indra Jaya Seafood Supplier, serta faktor penghambat dalam penerapan perlindungan hukum terhadap pekerja yang bekerja melebihi batas waktu kerja di perusahaan UD. Supplier Seafood Indra Jaya. Jenis penelitian yang digunakan dalam penelitian ini adalah penelitian hukum empiris. Hasil penelitian menunjukkan bahwa Perusahaan UD. Indra Jaya Seafood Supplier dalam mempekerjakan tenaga kerja lebih banyak dari waktu yang ditentukan undang-undang. Pasalnya, jika dijumlahkan, terkadang perusahaan diharapkan mempekerjakan pekerja lebih dari 14 jam dalam seminggu. Mengenai kewajiban pengusaha terhadap pekerja yang melebihi waktu kerja, perusahaan UD. Supplier Seafood Indra Jaya telah melakukannya secara optimal sesuai dengan peraturan perundang-undangan yang berlaku. Hal ini dikarenakan pekerja yang bekerja di luar jam kerja di perusahaan telah dimintai persetujuan terlebih dahulu, diberikan uang lembur, diberikan waktu istirahat yang cukup, serta menyediakan makanan dan minuman. Faktor penghambat dalam penerapan perlindungan hukum bagi pekerja yang melebihi jam kerja di perusahaan UD. Supplier Seafood Indra Jaya yaitu adanya tuntutan konsumen untuk mengirimkan barang tepat waktu (deadline), kinerja pekerja yang kurang maksimal dalam menyiapkan barang untuk dikirim, dan juga kurangnya tenaga yang dimiliki saat ini.
\end{abstract}

Kata Kunci: Perlindungan Hukum, Pekerja, Waktu Kerja.

\begin{abstract}
Work that is done outside working hours is something that is outside the obligations of the workers. This study aims to analyze the implementation of legal protection for workers who work outside of working time at the UD company. Indra Jaya Seafood Supplier, as well as inhibiting factors in the application of legal protection to workers who work beyond the working time limit at UD company. Indra Jaya Seafood Supplier. This type of research used in this research is empirical legal research. The results showed that the company UD. Indra Jaya Seafood Supplier in hiring more workers than the time stipulated by law. The reason is, if you add up, sometimes companies are expected to employ workers more than 14 hours a week. Regarding the obligations of employers to workers who exceed working hours, UD company. Indra Jaya Seafood Supplier has done it optimally in accordance with the prevailing laws and regulations. This is because workers who work outside working hours at the company have been asked for prior approval, are given overtime pay, are given adequate rest time, and provide food and drinks. The inhibiting factor in the application of legal protection for workers who exceed working hours at UD company. Indra Jaya Seafood Supplier, namely the demands of consumers to deliver goods on time (deadline), less than optimal performance of workers in preparing goods for delivery, and also a lack of manpower currently.
\end{abstract}

Keywords: Legal Protection, Workers, Working Time

\section{PENDAHULUAN}

Negara Indonesia merupakan Negara yang sedang aktif meningkatkan pembangunan di segala sektor dengan tujuan untuk kemakmuran rakyat Indonesia (Hosein, 2016). Pembangunan tersebut tentu didukung oleh para tenaga kerja yang tanpa mengenal lelah, bekerja untuk meningkatkan nama perusahaan tempat ia bekerja, serta memenuhi kebutuhan hidupnya dan keluarganya. Berdasarkan hal tersebut, maka sudah sewajarnya bagi pemerintah untuk melindungi dan memperhatikan para tenaga kerja ini, karena tanpa mereka pembangunan di Indonesia tidak bisa terlaksana (Ramaputra et al., 
2020). Perlindungan pekerja dapat dilakukan baik dengan cara memberikan tuntunan, maupun dengan cara meningkatkan pengakuan hak-hak asasi manusia, perlindungan fisik serta teknis serta sosial dan ekonomi melalui norma yang berlaku dalam lingkungan kerja tersebut (Abdusalam, 2009). Pekerja dalam dunia kerja tidak dibedakan baik laki-laki maupun perempuan. Peluang kerja tersebut disambut baik oleh masyarakat demi terwujudnya impian penghidupan yang layak seperti yang tertuang pada Pasal 27 ayat (2) UUD NRI 1945, yang menyebutkan bahwa "Tiap-tiap warga negara berhak atas pekerjaan dan penghidupan yang layak bagi kemanusiaan". Demikian juga pada Pasal 28 D ayat (2) UUD 1945 dicantumkan bahwa "Setiap orang berhak bekerja dan mendapat imbalan dan perlakuan yang adil dan layak dalam hubungan kerja".

Dalam undang-undang juga telah disebutkan bahwa negara dan pihak swasta mempunyai kewajiban untuk memperhatikan hak-hak pekerja seperti yang tercantum dalam Undang-Undang No. 13 Tahun 2003 Tentang Ketenagakerjaan. Undang-Undang No. 13 Tahun 2003 Tentang Ketenagakerjaan tersebut merupakan wujud daripada peran pemerintah dan pengusaha dalam melindungi setiap pekerja yang ada di Indonesia. Hal ini terutama terhadap pekerja yang bekerja pada perusahaan swasta karena kadang masih kurang mendapatkan perlindungan atas hak-haknya, khususnya bagi tenaga kerja yang bekerja melebihi waktu kerja. Waktu kerja adalah hal yang sangat penting untuk diperhatikan pada dunia ketenagakerjaan. Hal ini mengingat bahwa pekerja/buruh adalah manusia kodrati dengan segala keterbatasan fisik dan psikis serta disamping perannya sebagai salah satu faktor produksi maka perlu mengatur dan memperhatikan waktu kerja. Mengenai perlindungan hukum pada pekerja yang bekerja melebihi waktu kerja, sebenarnya telah diatur dalam Undang-Undang No. 13 Tahun 2003 tentang Ketenagakerjaan. Pada Pasal 77 ayat (1) UndangUndang No. 13 Tahun 2003 tentang Ketenagakerjaan, menyebutkan bahwa "Setiap pengusaha wajib melaksanakan ketentuan waktu kerja".

Dewasa ini, masih sering terjadi masalah terkait ketenagakerjaan walaupun peraturan yang mengatur ketenagakerjaan sudah ditetapkan, seperti yang kita ketahui juga bahwa dewasa ini banyak perusahaan-perusahaan yang berdiri dan berkembang dengan baik dan pesat, hal ini tentu saja mempengaruhi pekerja (Purnamawanti \& Zulkarnaen, 2004). Seperti salah satu masalah yang sering terjadi adalah pelanggaran jam atau waktu kerja tenaga kerja dan tidak membayarkan upah kerja lembur apabila pekerja bekerja melebihi waktu kerja yang sesuai pada peraturan yang telah tertuang pada Undang-Undang No. 13 Tahun 2003 Tentang Ketenagakerjaan. Salah satu perusahaan yang ingin diteliti terkait pelaksanaan perlindungan hukum terhadap pekerja yang bekerja melebihi waktu kerja, yaitu perusahaan UD. Indra Jaya Seafood Supplier. UD. Indra Jaya Seafood Supplier adalah perusahaan yang terletak di Kecamatan Kuta, Kabupaten Badung-Bali, yang bergerak sebagai pemasok ikan laut ke beberapa restoran dan hotel yang ada di Bali. Berdasarkan hasil pengamatan awal penulis, tidak jarang perusahaan tersebut memperkerjakan pekerja/karyawannya melebihi waktu kerja. Tentunya perusahaan memiliki alasan tertentu sehingga memperkerjakan pekerjanya melebihi waktu kerja, dan hal tersebut lah yang ingin peneliti teliti lebih lanjut. Masalah perlindungan hukum terhadap pekerja yang bekerja melebihi waktu kerja, merupakan suatu hal yang menarik untuk dibahas.

Berdasarkan paparan latar belakang diatas, maka penelitian ini bertujuan untuk mengetahui pelaksanaan perlindungan hukum terhadap pekerja yang bekerja melebihi waktu kerja pada pada perusahaan UD. Indra Jaya Seafood Supplier, dan untuk mengetahui faktor penghambat dalam pelaksanaan perlindungan hukum terhadap pekerja yang bekerja melebihi batas waktu kerja pada perusahaan UD. Indra Jaya Seafood Supplier.

\section{METODE PENELITIAN}

Jenis Penelitian yang dipergunakan pada penelitian ini adalah penelitian hukum empiris. Penelitian hukum empiris, yaitu kajian yang memandang hukum sebagai kenyataan, mencakup kenyataan sosial, kenyataan kultur dan lain-lain. Kajian ini bersifat deskriptif analitik, dimana kajian empiris mengkaji law in action. Kajian empiris dunianya adalah das sein (apa kenyataannya) (Ali \& Heryani, 2012). Pendekatan masalah yang dipergunakan adalah pendekatan sosiologi hukum. Pendekatan sosiologi hukum yaitu pendekatan yang dilakukan secara langsung ke lapangan, guna melihat langsung kenyataan sosial yang sebenarnya terjadi. Adapun sumber data yang digunakan yaitu bahan hukum primer yang artinya bahan hukum yang berpusat pada peraturan UU yang berlaku di Indonesia, dan 
bahan hukum sekunder yaitu bahan hukum yang diperoleh dari pengkajian kepustakaan. Bahan hukum yang telah dikumpulkan selanjutnya diolah menggunakan metode deduktif induktif atau sebaliknya, untuk memperoleh bahan hukum yang berkualitas sesuai dengan pokok masalah yang dibahas dan akhirnya berdasarkan bahan hukum yang diperoleh dari pengumpulan maupun pengelolaan-pengelolaan tersebut di atas lalu disajikan dalam bentuk jurnal secara deskriptif.

\section{HASIL DAN PEMBAHASAN}

\section{Pelaksanaan Perlindungan Hukum terhadap Pekerja yang Bekerja Melebihi Waktu Kerja} Pada Pada Perusahaan UD. Indra Jaya Seafood Supplier

Menurut Satjipto Raharjo, Teori perlindungan hukum bahwa hukum bertujuan mengintegrasikan serta mengkoordinasikan berbagai kepentingan dalam masyarakat karena dalam suatu lalu lintas kepentingan, perlindungan terhadap kepentingan tertentu dapat dilakukan dengan cara membatasi berbagai kepentingan di lain pihak (Raharjo, 2000). Menurut Muchsin, perlindungan hukum adalah kegiatan untuk melindungi individu dengan menyerasikan hubungan nilai-nilai atau kaidah- kaidah yang menjelma dalam sikap dan tindakan dalam menciptakan adanya ketertiban dalam pergaulan hidup antar sesama manusia (Muchsin, 2003).

Menurut C.S.T. Kansil, perlindungan hukum merupakan penyempitan arti dari perlindungan, dalam hal ini hanya perlindungan oleh hukum saja. Perlindungan yang diberikan oleh hukum, terkait pula dengan adanya hak dan kewajiban, dalam hal ini yang dimiliki oleh manusia sebagai subyek hukum dalam interaksinya dengan sesama manusia serta lingkungannya. Sebagai subyek hukum manusia memiliki hak dan kewajiban untuk melakukan suatu tindakan hokum (Kansil, 1989). Terkait bentuk perlindungan hukum terhadap tenaga kerja yang bekerja melebihi waktu jam kerja, hal tersebut telah diatur dalam Undang-Undang Nomor 13 Tahun 2003 tentang Ketenagakerjaan. Pada Pasal 77 ayat (1) Undang-Undang Ketenagakerjaan disebutkan bahwa bahwa Setiap pengusaha wajib melaksanakan ketentuan waktu kerja. Dan pasal 77 ayat (2) Undang-Undang Ketenagakerjaan menyebutkan bahwa, Waktu kerja sebagaimana dimaksud dalam ayat (1) meliputi:

a. 7 (tujuh) jam 1 (satu) hari dan 40 (empat puluh) jam 1 (satu) minggu untuk 6 (enam) hari kerja dalam 1 (satu) minggu; atau

b. 8 (delapan) jam 1 (satu) hari dan 40 (empat puluh) jam 1 (satu) minggu untuk 5 (lima) hari kerja dalam 1 (satu) minggu.

Selanjutnya Pasal 78 ayat (1) Undang-undang Nomor 13 Tahun 2003 Tentang Ketenagakerjaan menyebutkan bahwa, Pengusaha yang mempekerjakan pekerja/buruh melebihi waktu kerja sebagaimana dimaksud dalam pasal 77 ayat (2) harus memenuhi syarat:

a. Ada persetujuan pekerja/buruh yang bersangkutan; dan

b. Waktu kerja lembur hanya dapat dilakukan paling banyak 3 (tiga) jam dalam 1 (satu) hari dan 14 (empat belas) jam dalam 1 (satu) minggu. Dan Pasal 78 ayat (2) Undang-undang Ketenagakerjaan menyebutkan bahwa pengusaha yang mempekerjakan pekerja/buruh melebihi waktu kerja sebagaimana dimaksud dalam ayat (1) wajib membayar upah kerja lembur.

Mengenai kewajiban pengusaha memberikan upah bagi pekerja yang lembur, tercantum dalam Pasal 88 ayat 3 huruf b. Adapun Pasal 88 ayat 3 huruf b, menyebutkan bahwa upah kerja lembur merupakan salah satu bagian dari kebijakan pengupahan yang melindungi pekerja/buruh. Untuk peraturan pelaksananya, pada tahun 2004, Menteri Tenaga Kerja Dan Transmigrasi Republik Indonesia Menerbitkan Keputusan Menteri Tenaga Kerja Dan Transmigrasi Republik Indonesia Nomor Kep. 102/Men/Vi/2004 Tentang Waktu Kerja Lembur Dan Upah Kerja Lembur. Tekait pengaturan mengenai kewajiban pengusaha memperkerjakan buruh melebihi waktu jam kerja/lembur dan cara pengupahan diatur jelas dalam KepMen ini yaitu dari pasal 7-12. Adapun penjabaran dari pasal 7-12 Keputusan Menteri Tenaga Kerja Dan Transmigrasi Republik Indonesia Nomor Kep. 102/Men/Vi/2004 Tentang Waktu Kerja Lembur Dan Upah Kerja Lembur, antara lain; Pada pasal 7 diatur mengenai kewajiban pengusaha dalam memperkerjakan pekerja melebihi waktu jam kerja, adapun bunyi dari pasal tersebut adalah sebagai berikut: Pasal 7 (1) Perusahaan yang mempekerjakan pekerja/buruh selama waktu kerja lembur berkewajiban: membayar upah kerja lembur; memberi kesempatan untuk istirahat secukupnya; memberikan makanan dan minuman sekurang-kurangnya 1.400 kalori apabila kerja lembur dilakukan selama 3 (tiga) jam atau lebih. (2) Pemberian makan dan minum sebagaimana dimaksud dalam ayat (1) huruf c tidak boleh diganti dengan uang. 
Selanjutnya pada pasal 8 sampai dengan pasal 10 diatur mengenai sistem pemberian upah bagi pekerja yang bekerja melebihi waktu jam kerja, adapun bunyi pasal 8 sampai dengan pasal 10 tersebut, adalah sebagai berikut; " Pasal 8 (1) Perhitungan upah lembur didasarkan pada upah bulanan, (2) Cara menghitung upah sejam adalah 1/173 kali upah sebulan. Pasal 9 (1) Dalam hal upah pekerja/buruh dibayar secara harian, maka penghitungan besarnya upah sebulan adalah upah sehari dikalikan 25 (dua puluh lima) bagi pekerja/buruh yang bekerja 6 (enam) hari kerja dalam 1 (satu) minggu atau dikalikan 21 (dua puluh satu) bagi pekerja/buruh yang bekerja 5 (lima) hari kerja dalam 1 (satu) minggu. (2) Dalam hal upah pekerja/buruh dibayar berdasarkan satuan hasil, maka upah sebulan adalah upah rata-rata 12 (dua belas) bulan terakhir. (3) Dalam hal pekerja/buruh bekerja kurang dari 12 (dua belas) bulan sebagaimana dimaksud dalam ayat (2), maka upah sebulan dihitung berdasarkan upah rata-rata selama bekerja dengan ketentuan tidak boleh lebih rendah dari upah dari upah minimum setempat. Pasal 10 (1) Dalam hal upah terdiri dari upah pokok dan tunjangan tetap maka dasar perhitungan upah lembur adalah $100 \%$ (seratus perseratus) dari upah. (2) Dalam hal upah terdiri dari upah pokok, tunjangan tetap dan tunjangan tidak tetap, apabila upah pokok tambah tunjangan tetap lebih kecil dari $75 \%$ (tujuh puluh lima perseratus) keseluruhan upah, maka dasar perhitungan upah lembur $75 \%$ (tujuh puluh lima perseratus) dari keseluruhan upah".

Dan juga, Pada pasal 11 sampai dengan pasal 12 Keputusan Menteri ini diatur mengenai cara penghitungan upah kerja lembur, adapun bunyi pasal 11 sampai dengan pasal 12 tersebut, adalah sebagai berikut: "Pasal 11 Cara perhitungan upah kerja lembur sebagai berikut : Apabila kerja lembur dilakukan pada hari kerja: a.1. untuk jam kerja lembur pertama harus dibayar upah sebesar 1,5 (satu setengah) kali upah sejam; a.2. untuk setiap jam kerja lembur berikutnya harus dibayar upah sebesar 2 (dua) kali upah sejam.

Apabila kerja lembur dilakukan pada hari istirahat mingguan dan/atau hari libur resmi untuk waktu kerja 6 (enam) hari kerja 40 (empat puluh) jam seminggu maka: b.1. perhitungan upah kerja lembur untuk 7 (tujuh) jam pertama dibayar 2 (dua) kali upah sejam, dan jam kedelapan dibayar 3 (tiga) kali upah sejam dan jam lembur kesembilan dan kesepuluh dibayar 4 (empat) kali upah sejam. b. 2. apabila hari libur resmi jatuh pada hari kerja terpendek perhitungan upah lembur 5 (lima) jam pertama dibayar 2 (dua) kali upah sejam, jam keenam 3 (tiga) kali upah sejam dan jam lembur ketujuh dan kedelapan 4 (empat) kali upah sejam. Apabila kerja lembur dilakukan pada hari istirahat mingguan dan/atau hari libur resmi untuk waktu kerja 5 (lima) hari kerja dan 40 (empat puluh) jam seminggu, maka perhitungan upah kerja lembur untuk 8 (delapan) jam pertama dibayar 2 (dua) kali upah sejam, jam kesembilan dibayar 3(tiga) kali upah sejam dan jam kesepuluh dan kesebelas 4 (empat) kali upah sejam. Pasal 12 Bagi perusahaan yang telah melaksanakan dasar perhitungan upah lembur yang nilainya lebih baik dari Keputusan Menteri ini, maka perhitungan upah lembur tersebut tetap berlaku". Dilihat dari pengaturan dalam Keputusan Menteri diatas, mengenai Waktu Kerja Lembur Dan Upah Kerja Lembur secara rinci sudah diatur secara jelas. Maka dari itu, para pengusaha wajib untuk melaksanakannya.

UD. Indra Jaya Seafood Supplier merupakan perusahaan yang didirikan oleh Bapak I Nyoman Sudiasa, SE., yang beralamat di Jl. Pantai Kedonganan, Gang Mawar No 8 Kedonganan Kuta, Bali. Perusahaan ini bergerak dalam bidang usaha seafood supplier yang mempekerjakan sebanyak 10 pekerja. Pekerja di perusahaan ini dibagi dalam 4 bagian pekerjaan, yaitu: marketing, pembukuan, bagian gudang dan bagian pengiriman. Terkait waktu kerja dalam perusahaan tersebut, beliau menjelaskan bahwa waktu normal bekerja dalam perusahaannya yaitu dari Hari SeninSabtu, pukul 8.00-16.00 WITA. Selain itu, dalam sehari terkadang pekerja, bekerja melebihi waktu kerja lebih/lembur disaat-saat tertentu, yaitu kadang 2 jam dalam 1 hari (hari kerja normal perusahaan), serta kadang juga pada hari Minggu pekerja juga bekerja setengah hari, dari pukul 8.0012.00 WITA). (Hasil wawancara pada hari Senin, 15 Januari 2018)

Berdasarkan hasil wawancara diatas, terlihat bahwa perusahaan UD. Indra Jaya Seafood Supplier, dalam memperkerjakan pekerjanya melebihi waktu kerja yang ditetapkan oleh undangundang. Hal tersebut dikarenakan perusahaan UD. Indra Jaya Seafood Supplier memperkerjakan pekerjanya sampai dengan hari Sabtu, serta terkadang memperkerjakan pekerjanya pada hari SeninJumat, lebih dari 7 jam, dan juga terkadang pekerjanya bekerja pada Minggu. Apabila dijumlahkan, terkadang perusahaan tersebut diperkirakan dapat memperkerjakan pekerjanya lebih dari 14 jam dalam seminggu. Sebagaimana diketahui bahwa pasal 77 ayat (2) huruf b. Undang-Undang Nomor 
13 Tahun 2003 tentang Ketenagakerjaan, menyatakan bahwa; Waktu kerja lembur hanya dapat dilakukan paling banyak 3 (tiga) jam dalam 1 (satu) hari dan 14 (empat belas) jam dalam 1 (satu) minggu. Berdasarkan hal tersebut, maka dapat dikatakan pekerja pada perusahaan UD. Indra Jaya Seafood Supplier, bekerja melebihi waktu kerja, dan perusahaan tersebut wajib memenuhi kewajiban sebagaimana yang diatur dalam Pasal 7 Undang-Undang Nomor 13 Tahun 2003 tentang Ketenagakerjaan, yaitu Pada pasal 7 diatur mengenai kewajiban pengusaha dalam memperkerjakan pekerja melebihi waktu jam kerja, adapun bunyi dari pasal tersebut adalah sebagai berikut:

a. membayar upah kerja lembur;

b. memberi kesempatan untuk istirahat secukupnya;

c. memberikan makanan dan minuman sekurang-kurangnya 1.400 kalori apabila kerja lembur dilakukan selama 3 (tiga) jam atau lebih.

Terkait hal tersebut, berdasarkan keterangan Bapak I Nyoman Sudiasa, SE., dalam memperjakan pekerjanya melebihi waktu kerja, beliau sudah meminta persetujuan dari para pekerjanya sebelum memperkerjakan mereka melebihi waktu jam kerja. (Hasil wawancara pada hari Senin, 15 Januari 2018). Hal tersebut dikonfirmasi oleh salah satu pekerja di UD. Indra Jaya Seafood Supplier, yaitu Bapak I Putu Indra Prasetya Wiguna, selaku pekerja dalam bidang pengiriman. Berdasarkan penjelasan dari Bapak I Putu Indra Prasetya WIguna, beliau mengatakan bahwa memang benar dalam melakukan kerja lembur, para pekerja sudah dimintai persetujuan terlebih dahulu (Hasil wawancara pada hari Senin, 15 Januari 2018). Dalam hal meminta persetujuan kepada pekerja, hal tersebut sesuai dengan Pasal 1601 j KUHPerdata, yang didalamnya menyebutkan bahwa, suatu reglemen (peraturan perusahaan) yang ditetapkan oleh majikan hanya mengikat buruh, jika buruh telah menyatakan setuju dengan reglemen itu. Berdasarkan hal tersebut, maka wajib untuk seorang pengusaha meminta persetujuan terlebih dahulu kepada pekerja apabila ingin memperkerjakannya melebihi waktu jam kerja yang telah ditetapkan sebelumnya.

Untuk upah pekerja yang bekerja melebihi waktu jam kerja di UD. Indra Jaya Seafood Supplier, selanjutnya Bapak I Nyoman Sudiasa, SE. menjelaskan bahwa bagi pekerja yang bekerja melebihi waktu jam kerja, beliau berikan upah. Adapun upah yang diberikan beliau saat kerja melebihi waktu jam kerja yaitu berkisar Rp. 50.000 sampai dengan Rp. 100.000/hari, tergantung waktu jam kerja lebih, dan juga beban kerja lembur. Selain itu, beliau juga tidak lupa untuk memberikan mereka waktu istirahat yang cukup dan juga memberikan makanan dan minuman. Hal tersebut beliau ungkapkan demi alasan kemanusiaan, dan juga pekerja yang lembur dapat bekerja secara maksimal (Hasil wawancara pada hari Senin, 15 Januari 2018).

Dilihat dari beberapa penjelasan yang telah diuraikan diatas, perusahaan UD. Indra Jaya Seafood Supplier, dalam memperkerjakan pekerjanya melebihi waktu kerja yang ditetapkan oleh undang-undang. Hal tersebut dikarenakan apabila dijumlahkan, terkadang perusahaan tersebut diperkirakan dapat memperkerjakan pekerjanya lebih dari 14 jam dalam seminggu. Mengenai kewajiban pengusaha terhadap pekerja yang melebihi waktu jam kerja, perusahaan UD. Indra Jaya Seafood Supplier sudah melakukannya cukup optimal sesuai peraturan perundang-undangan yang berlaku. Hal tersebut dikarenakan pekerja yang bekerja melebihi waktu jam kerja di perusahaan tersebut sudah dimintai persetujuan terlebih dahulu, diberikan upah lembur, diberikan waktu istirahat yang cukup, serta memberikan makanan dan minuman.

\section{Hambatan dalam Pelaksanaan Perlindungan Hukum terhadap Pekerja yang Bekerja Melebihi Batas Waktu Kerja Pada Perusahaan UD. Indra Jaya Seafood Supplier}

Dalam pelaksanaan perlindungan hukum terhadap pekerja tentunya akan timbul hambatan-hambatan serta apa saja yang berkaitan dengan perwujudan perlidungan hukum terhadap pekerja. Dalam hal ini adanya banyak aspek yang akan menghambat perwujudan perlindungan hukum terhadap pekerja, antara lain prosedur pelaksaan yang tidak sesuai dengan ketentuan serta hubungan pengusaha dan pekerja dalam perwujudan pelaksanaan perlindungan hukum. Berdasarkan penjelasan dari Bapak I Nyoman Sudiasa, SE., selaku pemilik/owner perusahaan UD. Indra Jaya Seafood Supplier, dalam pelaksanaan perlindungan hukum terhadap pekerjanya, tidak jarang beliau mengalami hambatanhambatan. Ketentuan yang ada dalam peraturan perundang-undangan kadang tidak bisa dilakukan sepenuhnya karena dalam situasi dan kondisi tertentu tidak memungkinkan untuk menaati 
sepenuhnya, terlebih lagi dalam bidang bisnis distribusi yang penuh dengan tuntutan dari pihak konsumen (Hasil wawancara pada hari Senin, 15 Januari 2018).

Adapun faktor penghambat pelaksanaan perlindungan hukum kepada pekerja yang bekerja melebihi waktu jam kerja pada perusahaan UD. Indra Jaya Seafood Supplier, antara lain sebagai berikut:

1. Adanya Tuntutan Konsumen Untuk Mengirim Barang Tepat Waktu (Deadline)

Berdasarkan penjelasan dari Bapak I Nyoman Sudiasa, SE., beliau mengatakan bahwa tuntutan konsumen yang membeli barangnya untuk mengirim barang tepat waktu merupakan salah satu faktor penghambat untuk melaksanakan ketentutan waktu jam lembur sesuai undang-undang. Berdasarkan slogan bisnis "konsumen adalah raja", adalah pedoman yang mendasarinya melakukan hal tersebut. Terlebih lagi perusahaan UD. Indra Jaya Seafood Supplier saat ini mempunyai beberapa langganan yang cukup banyak, hingga ke restaurant dan hotel yang berada di Ubud, Gianyar. Selain itu, melihat persaingan usaha dewasa ini rasanya apabila kita tidak memperhatikan tuntutan konsumen, maka konsumen akan berpaling kepada perusahaan pesaingnya, maka dari itu terkadang untuk mengirim barang ke konsumen, beliau memerlukan tenaga dan waktu ekstra para pekerjanya dengan memperkerjakan melebihi waktu jam kerja normal, dan kadang melebihi waktu jam kerja normal yang dibolehkan oleh undang- undang. Mau tak mau hal tersebut merupakan hal yang sulit untuk dihindari, hal ini demi memenuhi kebutuhan ekonomi, dan persaingan usaha yang kian lama kian ketat (Hasil wawancara pada hari Senin, 15 Januari 2018).

2. Kurang Maksimalnya Kinerja Pekerja Untuk Menyiapkan Barang Yang Akan Dikirim

Selain faktor adanya tuntutan konsumen untuk mengirim barang tepat waktu (deadline), kurang maksimalnya kinerja pekerja untuk menyiapkan barang yang akan dikirim juga menjadi salah satu faktor penghambat untuk melaksanakan ketentuan waktu kerja lembur sesuai peraturanperundang-undangan yang berlaku. Berdasarkan penjelasan dari Bapak I Nyoman Sudiasam, SE., terkadang dalam pekerjanya juga dalam menyiapkan barang yang akan dikirim kurang maksimal, sehingga perlu dilakukan tambahan waktu kerja untuk memaksimalkan pekerjaannya. Hal tersebut menurut beliau adalah hal yang manusiawi, karena manusia tidak luput juga dari kesalahan. Sebagai contoh, disaat beliau memantau persiapan barang yang ingin dikirimkan ke konsumen, tidak jarang beliau melihat persiapannya masih terdapat beberapa kekurangan. Tentu sebagai perusahaan yang mementingkan kualitas barang terhadap konsumen, beliau ingin konsumennya mendapatkan barang dengan hasil yang memuaskan. Maka dari itu apabila beliau melihat masih terdapat barang yang belum sesuai, beliau menerapkan waktu kerja lembur untuk pekerjanya, itupun beliau selalu meminta persetujuan dari pekerjanya (Hasil wawancara pada hari Senin, 15 Januari 2018)

3. Kurangnya Tenaga Kerja Yang Dimiliki Saat Ini Sebagaimana yang diketahui bahwa UD. Indra Jaya Seafood Supplier memiliki pekerja tetap sejumlah 10 orang yang dibagi ke beberapa bidang pekerjaan. Namun, jumlah pekerja tersebut, dirasa masih kurang, terlebih lagi apabila terdapat order barang yang memerlukan tenaga lebih, tentu jumlah tersebut masih kurang.

Berdasarkan penjelasan dari Bapak I Nyoman Sudiasa, SE., terkadang perusahaannya menerima pesanan barang dalam jumlah yang besar. Terlebih lagi perusahaan UD. Indra Jaya Seafood Supplier ini juga melakukan pengiriman hingga diluar kabupaten Badung, yang dimana dalam perjalanan tidak jarang ditemui kemacetan. Melihat keadaan tersebut, dengan jumlah pekerja yang ada, mau tidak mau disaat terdapat pesanan barang dengan jumlah besar, beliau harus memperkerjakan pekerjanya melebihi waktu jam kerja yang diamanatkan oleh peraturanperundangan. Beliau juga mengatakan bahwa sulit rasanya apabila tidak memperkerjakan pekerja melebihi waktu jam kerja dengan jumlah pekerja yang dimilikinya saat ini (Hasil wawancara pada hari Senin, 15 Januari 2018).

\section{SIMPULAN DAN SARAN}

\section{Simpulan}

Berdasarkan hasil pembahasan di atas, dapat disimpulkan bahwa Perusahaan UD. Indra Jaya Seafood Supplier, dalam memperkerjakan pekerjanya melebihi waktu kerja yang ditetapkan oleh undangundang. Hal tersebut dikarenakan apabila dijumlahkan, terkadang perusahaan tersebut diperkirakan 
dapat memperkerjakan pekerjanya lebih dari 14 jam dalam seminggu. Mengenai kewajiban pengusaha terhadap pekerja yang melebihi waktu jam kerja, perusahaan UD. Indra Jaya Seafood Supplier sudah melakukannya cukup optimal sesuai peraturan perundang-undangan yang berlaku. Hal tersebut dikarenakan pekerja yang bekerja melebihi waktu jam kerja di perusahaan tersebut sudah dimintai persetujuan terlebih dahulu, diberikan upah lembur, diberikan waktu istirahat yang cukup, serta memberikan makanan dan minuman. Adapun faktor penghambat dalam pelaksanaan perlindungan hukum bagi pekerja yang melebihi waktu jam kerja di perusahaan UD. Indra Jaya Seafood Supplier, yaitu adanya adanya tuntutan konsumen untuk mengirim barang tepat waktu (deadline), kurang maksimalnya kinerja pekerja untuk menyiapkan barang yang akan dikirim, dan juga kurangnya tenaga kerja yang dimiliki saat ini.

\section{Saran}

Adapun saran yang dapat diberikan berdasarkan pembahasan ini antara yakni Sebaiknya para pengusaha lebih memperhatikan lagi ketentuan yang terdapat dalam peraturan perundang-undangan terkait perlindungan hukum terhadap pekerja, karena dalam hukum ketenagakerjaan di Indonesia, para pekerja tersebut memiliki hak-hak yang perlu dipenuhi oleh para pengusaha. Kemudian, sebaiknya pemerintah selain memperhatikan para pekerja, juga memperhatikan para pengusaha, hal tersebut dikarenakan tidak semua yang terdapat dalam perundang-undangan masih sesuai dengan kondisi sekarang, mengingat persaingan usaha kian menguat, dan hukumpun seharusnya harus bisa menyesuaikan.

\section{DAFTAR PUSTAKA}

Abdusalam. (2009). Hukum Ketenagakerjaan (Edisi Revi). Restu Agung.

Ali, A., \& Heryani, W. (2012). Menjelajahi Kajian Empiris terhadap Hukum. Prenamedia Group.

Hosein, Z. A. (2016). Peran Negara Dalam Pengembangan Sistem Ekonomi Kerakyatan menurut UUD 1945. Jurnal Hukum IUS QUIA IUSTUM, 23(3), 503-528.

Kansil, C. S. T. (1989). Pengantar Ilmu Hukum dan Tata Hukum Indonesia. Balai Pustaka.

Muchsin. (2003). Perlindungan dan Kepastian Hukum bagi Investor di Indonesia. Magister Ilmu Hukum Program Pascasarjana Universitas Sebelas Maret.

Purnamawanti, P., \& Zulkarnaen, I. (2004). Permasalahan Hukum Tentang Tenaga Kerja Anak di Indonesia. Lex Jurnalica, 2(1), 29-68.

Raharjo, S. (2000). Ilmu Hukum. PT Citra Aditya Bakti.

Ramaputra, N. A., Budiartha, I. N. P., \& Seputra, I. P. G. (2020). Perlindungan Hukum Terhadap Pekerja yang Melebihi Batas Waktu Kerja di PT. Adi Putra Denpasar. Jurnal Analogi Hukum, 2(2), 240-245. 